\title{
Caamembecaia gratiosus n. gen., n. sp. (Acari: Trombiculidae), from Trinomys gratiosus (Gunter) (Rodentia: Echimydae), of Atlantic Forest in Southeastern Brazil
}

\author{
Gilberto S Gazêta/ ${ }^{+}$, Marinete Amorim, David EP Bossi* , Arício X Linhares**, \\ Nicolau M Serra-Freire
}

\author{
Laboratório de Ixodides, Departamento de Entomologia, Instituto Oswaldo Cruz-Fiocruz, Av. Brasil 4365, 21040-900 \\ Rio de Janeiro, RJ, Brasil *Coordenação de Proteção de Espécies da Fauna, Ibama Brasília, DF, Brasil **Departamento de \\ Parasitologia, Instituto de Biologia, Unicamp, Campinas, SP, Brasil
}

From June 1999 to May 2001, small mammals were captured in three areas of the Atlantic Forest in Southeastern Brazil and examined for ectoparasites. Analysis of ectoparasites revealed the presence of a new chigger genus and species, Caamembecaia gratiosus, from Trinomys gratiosus. This is the first record of a chigger from $\mathrm{T}$. gratiosus.

Key words: Caamembecaia gratiosus n. gen., n. sp.- Trombiculidae - rodent - Brazil

Larval Trombiculidae or chigger mites, have a world distribution and parasitize all classes of terrestrial vertebrates and some invertebrates (Krantz 1978, Zhang 1998). Chigger bites can produce a dermatitis called trombidiosis with itching and swelling at the site of attachment in man and animals. This dermatitis may be accompanied by secondary infections and persistent lesions. In addition, some species transmit Orientia tsutsugamushi, scrub typhus agent, an important public health disease in Southeast Asia (Wharton \& Fuller 1952, Jensenius et al. 2004).

The number of described chiggers species world wide is approaching 3000, with 87 genera currently recognized of Neartic and Neotropical faunal regions (Brennan \& Goff 1977, Goff \& Gettinger 1989, 1991, Wilson et al. 1989).

This paper describe a new genus of chigger found on Trinomys gratiosus (Gunter) (Rodentia: Echimydae), of Atlantic Forest in Southeastern Brazil. Fiocruz.

The type is deposited in the Instituto Oswaldo Cruz-

\section{MATERIALS AND METHODS}

From June 1999 to May 2001, 546 small mammals representing 15 genera and 21 species, from the Serra da

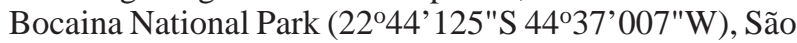
José do Barreiro/São Paulo (SP), Serra da Fartura (2153621'S 4645188'W), São João da Boa Vista/SP, and Itatiaia National Park (22 $\left.26^{\prime} 187^{\prime \prime S} 44^{\circ} 37^{\prime} 511^{\prime \prime W}\right)$, Itatiaia/ $\mathrm{RJ}$, areas of the Atlantic Forest in Southeastern Brazil were captured and examined for ectoparasites. The collecting sites were separated by the Paraíba do Sul river valley (Bossi 2003). Analysis of ectoparasites revealed the pres-

Financial support: Fapesp (process 98/01296-9) for funding the field research; Unicamp, Unifeob, Uerj, and Ibama (processes 02001,005474/98-9, and 2027.008759/99-81 SP)

+Corresponding author: gsgazeta@ioc.fiocruz.br

Received 22 August 2005

Accepted 15 February 2006 ence of a larva representing a new genus of chigger recovered from T. gratiosus, captured in the Itatiaia National Park. The generic diagnosis follows Wharton and Fuller (1952), Brennan and Jones (1959), Brennan and Goff (1977), and the descriptions follows Fonseca (1955), Vercammen-Grandjean et al. (1970), Goff and Gettinger (1991). All measurements are given in micrometers. Terminology follows Goff et al. (1982)

\section{RESULTS \\ Caamembecaia n.gen.}

Type species: Caamembecaia gratiosus n.sp.

Diagnosis: Trombiculinae larvae with 7-segemented legs; two genuala I, one genuala II, one guenuala III; tibiala III present, no mastibiala III; subterminala and parasubterminala present; coxa III with one setae. Palpal tarsus 4B; galeala N; palpal claw 3-pronged; cheliceral blade with tricuspid cap. Scutum subrectangular, with foliate AL and PL setae; sensillae broadly capitate, with heavy barbs. Eyes present, 2/2, intrascutal. Dorsal setae foliate. Sternal and preanal setae branched. Postanal setae foliate.

\section{Caamembecaia gratiosus n.sp.}

(Figs 1, 2)

Description - Idiosoma: $223 \mu \mathrm{m}$ of length and $175 \mu \mathrm{m}$ of width $(223 \times 175)$. Eyes $2 / 2$ intrascutal; 30 foliate dorsal opisthosomal setae, inserted on platelets and arranged in irregular rows, measuring 46-88; humeral setae, 73-74 long, are inserted on platelets; two pairs of sternal setae; anterior measuring 42-43 and posterior measuring 41-42; 28 branched preanal setae, measuring $31-43 ; 12$ postanal setae, similar in form to dorsal idiosomal setae, measuring 45-62; total idiosomal setae 79.

Gnathosoma: palpal setal formula B/B/BNB/4B; galeala $\mathrm{N}$; palpal claw 3-pronged; cheliceral blade (31-32) with tricuspid cap; gnathobase punctate, bearing a pair of branched setae.

Scutum: punctate, especially in the lateral areas, with anterior and posterior margins straight; anterior corners 


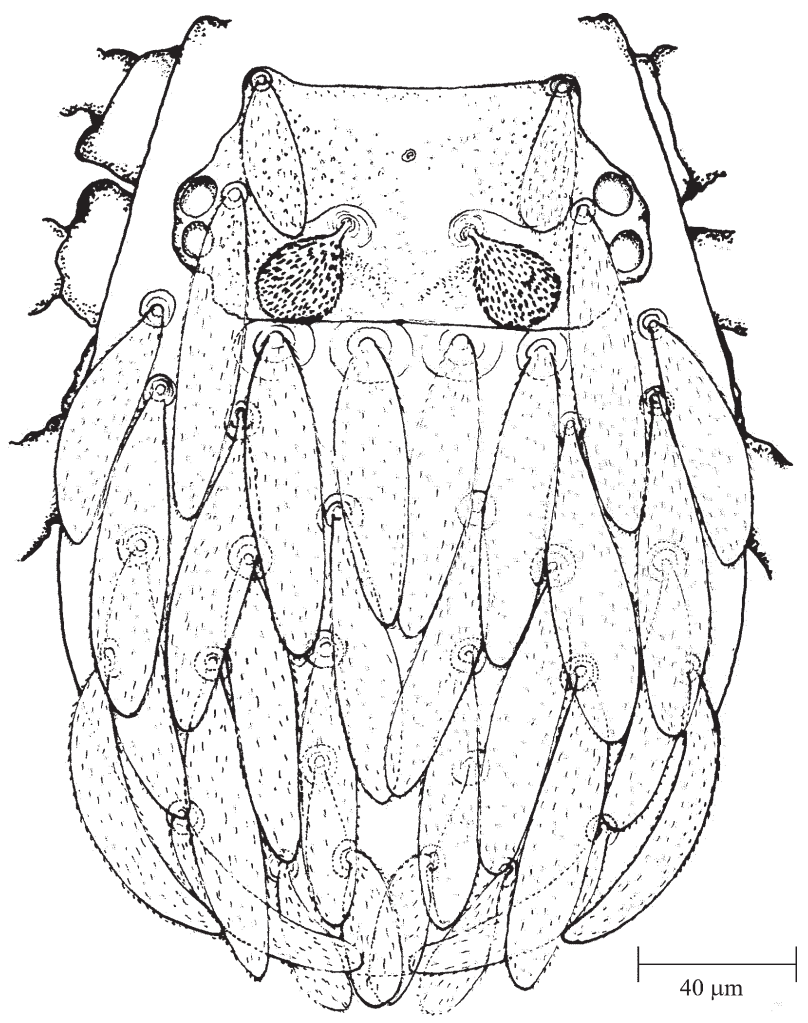

Fig. 1: larva of Caamembecaia gratiosus n. gen., n. sp. Dorsal view of idiosoma and gnathosoma. slightly prominent; base of AM setae posterior to AL bases; bothridial bases slightly posterior to the PL bases; AL and PL setae similar in form to dorsal idiosomal setae; sensillae capitate, head with fine setules; $\mathrm{PW} / \mathrm{SD}=1.36$; $\mathrm{AW}=76 ; \mathrm{PW}=87 ; \mathrm{SB}=30 ; \mathrm{ASB}=40 ; \mathrm{PSB}=24 ; \mathrm{AM}$ missing; $\mathrm{AL}=44 ; \mathrm{PL}=90 ;$ sensillae $=34 ; \mathrm{AP}=30$.

Legs: all 7-segmented; terminating in a pair of claws and a clawlike empodium. Onychotriches absent. IP $=710$. Leg I: 256; coxa with 1 branched seta (1B); trochanter 1B; basifermur 1B; telofemur 5B; genu 6B; 2 genualae; microgenuala; tibia 11B, 2 tibialae, microtibiala; tarsus (64 $\times 27)$ 19B; tarsala (19), parasubterminala, subterminala, pretarsala. Leg II: 202; coxa 1B; trochanter 1B; basifermur 2B; telofermur 4B; genu 3B; genuala; tibia 6B, 2 tibialae; tarsus $(57 \times 26) 14 \mathrm{~B}$, tarsala (16), microtarsala, pretarsala. Leg III: 252; coxa 1B; trochanter 1B; basifemur 2B; telofemur 3B; genu 4B, genuala; tibia 6b, tibiala; tarsus $(68 \times 19) 15 \mathrm{~B}$.

Holotype is deposited in the Instituto Oswaldo Cruz/ Fiocruz (Coleção Ixodológica do IOC - 0074/ACA).

Type material: Holotype: Itatiaia National Park, Rio de Janeiro State, Brazil, 1.170 m altitude, 20-VIII-1999, collector David Eduardo Paolinetti Bossi, ex Trinomys gratiosus (UFRJ, National Museum, MNRJ 67498).

\section{DISCUSSION}

Among the genera of Trombiculidae of western hemisphere, Caamembecaia is similar to Trombewingia


G

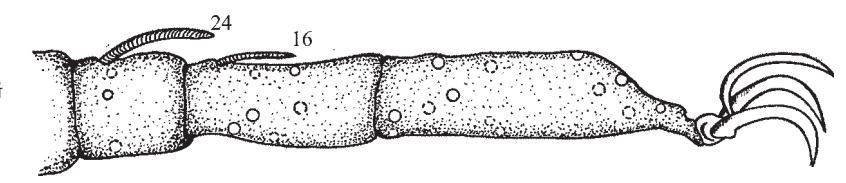

Fig. 2: larva of Caamembecaia gratiosus n. gen., n. sp. A: scutum; B: dorsal aspect of gnathosoma; C: ventral aspect of palpal tibia and tarsus; D: humeral seta (HS) and anterior dorsal idiosomal seta (ADS). E: leg I distal three segments showing specialized setae (numbers are measurements in micrometers) and bases of branched setae; F: leg II as above; G: leg III as above. 
(Fonseca 1955), in having palpal tarsus 4B; subterminala and parasubterminala present; coxa III with one setae; cheliceral bladewith a tricuspid cap; dorsal idiosomal and scutal setae foliate; sensillae expanded. However may be separated from Trombewingia in having two guenuala I (three guenualae I in Trombewingia) and eyes intrascutal (extrascutal in Trombewingia). The etymology of the generic name is based on the characteristics of the dorsal setae (derived from Caàmembeca a Brazilian Tupi dialect word meaning flabby leaf, flexible) and that of the specific name is from the host species. T. gratiosus is reported as a host for chiggers for the first time.

\section{ACKNOWLEDGEMENTS}

To Paulo César da Silveira for final art of drawing and Dr Lena Geiser, Department of Zoology, Uerj, for the identification of the host.

\section{REFERENCES}

Bossi DEP 2003. Associações entre Artrópodes e Pequenos Mamíferos Silvestres de Três Áreas Serranas do Sudeste Brasileiro, Unicamp, Campinas, 166 pp.

Brennan JM, Goff ML 1977. Keys to the genera of chiggers of the western hemisphere (Acarina: Trombiculidae). $J$ Parasitol 63: 554-566.

Brennan JM, Jones EK 1959. Keys to the chiggers of North America with synonymic notes and descriptions of two new genera (Acarina: trombiculidade). Ann Entomol Soc Am 52: 7-16.

Fonseca F 1955. Acarological notes XXXVII - Schoengastia
(Trombewingia) bakeri, subg. n., sp. n., and notes on the parasitism of man by chigger mites from Brazil (Acari: Trombiculidae). Rev Brasil Ent 3: 1-12.

Goff ML, Gettinger D 1989. Two new species of Schoengastiine chiggers (Acari: Trombiculidae) from Brazil and rediagnosis of Arisocerus Brennan, 1970. J Med Entomol 26: 554-558.

Goff ML, Gettinger D 1991. Two new species of chiggers (Acari: Trombiculidae) from small mammals collected in Brazil. J Med Entomol 28: 401-404.

Goff ML, Loomis RB, Welbourn WC, Wrenn WJ 1982. A glossary of chigger terminology (Acari: Trombiculidae). J Med Entomol 19: 221-238.

Jensenius M, Fournier PE, Raoult D 2004. Rickettsioses and the international traveler. Clin Infec Dis 39: 1493-1499.

Krantz GW 1978. A Manual of Acarology, 2nd ed., Oregon State University, Corvallis, 509 pp.

Vercammen-Grandjean PH, Rohde Jr CJ, Mesghali H 1970. Twenty larval trombiculidae (Acarina) from Iran. J Parasitol 56: 773-806.

Wharton GW, Fuller HS 1952. A Manual of the Chiggers, Entomological Society of Washington, Washington D.C., 185 pp.

Wilson N, Dietz JM, Whitaker JO 1989. Ectoparasitic Acari found on golden lion tamarins (Leontopithecus rosalia rosalia) from Brazil. J Wild Dis 25: 433-435.

Zhang ZQ 1998. Biology and ecology of trombidiid mites (Acari: Trombidioidea). Exp Apll Acarol 22: 139-155. 